\title{
The Determination of Green Infrastructure Components of Van City Center and Its Near Surroundings
}

\author{
Ayse Demir \\ Dep. of Landscape Architecture, Ankara University Graduate School of Applied Sciences, \\ E-mail: aysedemir_56@hotmail.com. \\ Emel Baylan \\ Dep. of Landscape Architecture, Faculty of Architecture and Design, Van Yuzuncu Yil University
}

E-mail: emelbaylan@yyu.edu.tr

The research is developed as a part of the first author's master thesis that was prepared under the supervision of second author.

\begin{abstract}
The planning and application of green infrastructure (GI) system contribute to protection of nature and the quality of urban life by supporting the ecological, economic and social functions of urban areas. Uncontrolled urban sprawl, illegal settlement and land use which neglects the sustainability of landscapes and open-green spaces negatively affect both the ecosystem functions in the city of Van and its immediate surroundings and the quality of urban life. Accordingly, the aim of this study was to determine the current state of the green infrastructure components of the city of Van and its surroundings in order to inform green infrastructure planning. To determine these components, consisting of the elements such as core areas, and corridors, nine ecological and cultural parameters were chosen; soil composition, vegetation, important natural areas and habitats, hydrological elements, slope, land use/land cover, protected areas, transportation networks and population density. In the study, following the field observations, the analytical procedures were completed using the Spatial Analyst and 3D Analyst tools in the ARCGIS 10.2 software. Ten core areas, sixteen matrixs and four corridors were determined as the green infrastructure components in the study area. The fact that more than $50 \%$ of the study area proved to be made up of green infrastructure components shows that the existing green infrastructure in the city and its near surroundings are interconnected. Core areas are mainly composed of wetland habitats along the shores of Lake Van and its tributaries, and a relatively smaller proportion of which were steppe, made up a small area $(15 \%)$ in the study. The limited, small area covered by the core areas points to the threat of landscape fragmentation in wetland and steppe habitats in the study area as well as to biodiversity loss. The lack of green infrastructure components in Van city center and the determination that this region is unsuitable for the development of green infrastructure components shows that urgent attention should be given to the development of large and small green areas within the city. Taking both natural and historical protected areas together when choosing parameters for determining the GI components ensured that the core areas were assessed as important GI components not only in terms of their ecological functions, but also taking their cultural values into account. With this kind of integrated approach in planning future green infrastructure system in the city, core areas can play a role in protecting natural and cultural landscape components as well as providing cultural ecosystem services.
\end{abstract}

Keywords: Urban Sprawl, Wetlands, Steppe Habitat, Natural and Cultural Protected Areas, Open-Green Spaces

DOI: $10.7176 / \mathrm{JSTR} / 5-2-38$

\section{Introduction}

Although land use trends and planning strategies may vary geographically, pressure on habitats and natural green spaces have been increased throughout the world by urban population increase, urban land use, urban sprawl, linear transportation lines, energy infrastructure and the filling- of rivers since the mid- 
1990s. Neglecting ecological structure and processes in urban land use decision making can lead to the degradation of the integrity and diversity of landscape structures, damage to ecosystem functions in natural areas and urban green spaces, and the fragmentation or even destruction of habitats (Ahern, 1995; Weber et al., 2007). As a result, quality of urban life and the sustainability of cities decrease. Therefore, in order to ensure the healthy continuation of ecological processes in urban areas and improve urban quality of life, landscape planning strategies and tools are needed which will help to functionally and physically establish and strengthen the sustainability of the ecosystems within cities and their near surroundings.

Since the mid- $20^{\text {th }}$ century, new local planning approaches and strategies have been used as alternatives to the existing conservation and local planning strategies in order to prevent habitat fragmentation, biodiversity loss and degradations on ecosystem functions as well as to create functional bonds between natural and cultural landscape elements. According to Jongman and Pungetti (2004) and Coşkun Hepcan (2008), the general aim of these planning approaches and strategies within the concepts of ecological network, green corridor, green road and green infrastructure, is to forge and renew the physical and functional connections between fragmented habitats and thereby, protect and improve the ecological and cultural functions and benefits of landscapes. As such, these plans and strategies, prepared with a sustainable approach to landscape planning and management, aim to improve the quality of urban life at the same time (Coşkun Hepcan, 2008; Lovell andTaylor, 2013).

The green infrastructure strategic approach is one of the above-mentioned planning approaches, and has been used frequently since the beginning of the $21^{\text {st }}$ century for urban development and landscape conservation. As stated by Benedict and McMahon (2012), green infrastructure that consists of interconnected green areas is a strategic approach which creates solutions to the problems of land conservation, the ecological and social effects of urban sprawl, and the rapid fragmentation of landscapes. Weber et al. (2006), Ahern (2007) and Mell (2009) describe green infrastructure as a tool for organizing urban areas in order to protect and support the integrity of ecological and cultural functions landscapes and for ensuring the sustainability of urban areas by taking into account the existing city structure, opengreen spaces, ecosystems and habitats. Green infrastructure is defined by the European Commission (2013) as a network system which, in both rural and urban environments, includes the connection between high-quality natural and semi-natural areas and other landscape elements, and is designed and managed to preserve bio-diversity and multifunctionality of ecosystems. Accordingly, the green infrastructure planning and design process include natural and man-made elements and solutions that allow humans' access to ecosystem services and promote the conservation of natural and cultural resources (Civic and Siuta, 2014). Like roads and other services that are necessary for modern populations, green infrastructure provides ecosystem services that are necessary for human welfare as those provided by built infrastructure. Therefore, just as growing and developing populations need the renewal and development of gray infrastructure systems such as roads, sewers and public services, there is also a need for green infrastructure system development for today's cities.

Parks, schoolyards, house gardens, roof gardens, hobby gardens, playgrounds, athletic fields, agricultural areas, lakes, forests, wetlands, rivers and other habitats within cities and in their near surroundings and natural, and cultural areas with different specialties and sizes such as vertical plantings, cemeteries, historical areas and vacant lots, build the basic elements of existing green infrastructure or that which is under planning (Weber et al., 2006;Goddard et al., 2010). According to Benedict and McMahon (2012), these natural and cultural areas of green infrastructure are connected to each other through components of green infrastructure, which are centers (core/patch), links (corridors) and matrixs. Cores are natural and cultural areas that are richer in biodiversity than other green infrastructural components. Benedict and McMahon (2012) state that cores are non-linear, relatively homogenous areas that are different from their surroundings and which serve more than one function, such as providing wildlife habitat, creating food sources for different life forms, and continuation of ecological processes. Corridors are linear areas or structures in the form of crossings or canals with ground cover types different from their surroundings, and which serve many purposes such as allowing for plant, animal, nutrient, water and wind movement. The other components of green infrastructure, matrixs, are landscape components different from corridors and core areas while providing connection between them. There is a high degree of connections in matrixs, and they have a homogenous land cover (Forman, 1995; Ahern, 2007;Coşkun Hepcan, 2008). Examples of green infrastructure components are shown in Table 1.

Green infrastructure systems have significant potential for developing sustainable urban by creating solutions to ecologic, economic and social problems, ensuring landscape connectivity and by providing multiple ecosystem services with an integrated approach (Benedict and McMahon, 2012; Mell, 2009). Examples of ecosystem services of urban green infrastructure are shown in Table 2. 
Table1.Sample landscapes and elements of green infrastructure components (adapted from Benedict and McMahon, 2006 and Ahern, 2007)

\begin{tabular}{|c|c|c|}
\hline Core areas & Connection/Link (Corridor) & Matrix \\
\hline $\begin{array}{l}\text { - Protected areas (e.g.; nature } \\
\text { reserves, wildlife area, } \\
\text { regional and national parks) } \\
\text { - Cemeteries } \\
\text { - Wetlands } \\
\text { - Urban parks } \\
\text { - Forest patches or grassland } \\
\text { patches }\end{array}$ & $\begin{array}{l}\text {-Rivers } \\
\text { - Riverbeds } \\
\text { - Roads } \\
\text { - Drainage lines, canals } \\
\text { - Tree belts, tree lines }\end{array}$ & $\begin{array}{l}\text {-Vacant lots } \\
\text { - Residential areas } \\
\text {-Industrial areas } \\
\text { - Waste disposal areas } \\
\text { - Multi-use areas } \\
\text { - Trade areas } \\
\text { - Green roofs / Roof gardens } \\
\text {-Agricultural areas }\end{array}$ \\
\hline
\end{tabular}

Table 2.Ecosystem services of urban green infrastructure (adapted from Ahern, 2007 and the European Environment Agency, 2017)

\begin{tabular}{|c|c|c|}
\hline Abiotic & Biotic & Cultural \\
\hline $\begin{array}{l}\text {-Interaction between surface } \\
\text { and ground water } \\
\text { - Soil formation } \\
\text { - Sustainability of the } \\
\text { hydrologic regime } \\
\text { - Rainwater management } \\
\text { - Nitrogen cycle } \\
\text {-CO2and greenhouse gas } \\
\text { retention } \\
\text { - Air quality regulation } \\
\text { - Climate regulation } \\
\text { - Reduction of thermal comfort } \\
\text { and energy use through roof } \\
\text { gardens }\end{array}$ & $\begin{array}{l}\text { - Habitat formation for life } \\
\text { forms } \\
\text { - Allowing and supporting the } \\
\text { movement of life forms } \\
\text { - Biomass creation } \\
\text { - Creating a genetic reserve } \\
\text { - Prevention of isolation } \\
\text { between species } \\
\text { - Supporting the interaction } \\
\text { between flora and fauna }\end{array}$ & $\begin{array}{l}\text { - Direct experience of nature } \\
\text { - Physical recreation } \\
\text { - Promotion of mental health } \\
\text { - Experience and conservation } \\
\text { of cultural heritage } \\
\text { - Acting as a source of } \\
\text { inspiration for artistic and } \\
\text { social activities } \\
\text { - Providing opportunities for } \\
\text { healthy social interaction } \\
\text {-Environmental education }\end{array}$ \\
\hline
\end{tabular}

The designated study area, Van city center and its near surroundings, is an area of both national and international importance in terms of both biodiversity and landscape variety due to its geographical location, the rare geological, geomorphological and hydrological structures unique to it and due to being in the Iran-Turan phytogeographical region. As such, different ecosystems, such as mountain, lake, river and steppe co-exist in the area. However, the green spaces and natural habitats in the area are being fragmented and destroyed as a result of rapidly increasing population, unplanned construction and urban sprawl. In addition to construction and urban land use decisions that neglect ecological processes and landscape integrity, open-green space development that fail to take local conditions and needs into account (e.g., the filling-in of the shore of Van Lake) and the lack of management plans for natural and cultural landscapes of national and local significance threaten the sustainability of the natural and cultural landscapes in the city of Van. The existing natural and man-made open-green areas in the study, which are few in number and cover extremely narrow areas, are separate from one another and they are also inadequate to meet the needs of the current population. According to the Turkish Statistics Institute, the population of Van in 2017 was about 1.107 million and it is expected to reach 1.153 million by 2023 (TÜİK 2018). Around 500,000 of this population live in the city center. This situation renders even more necessary the strengthening of the green infrastructure components and system of the city center and its near surroundings, which are already weak in terms of GIC. There is $250,000 \mathrm{~m}^{2}$ of GIC in the city center; thus, the amount of green area per person in Van city is approximately $2 \mathrm{~m}^{2}$. However, according to Building Law number 3194, the required amount of green area per person is at least seven square meters. Thus, a green infrastructure system needs to be developed in Van and its near surroundings which takes into account the existing natural and cultural landscape qualities and their potential.

In this context, the aim of the study was to determine appropriate areas and green infrastructure components (GIC) as a guide to developing a green infrastructure system by analyzing the existing 
conditions of natural and man-made open-green spaces in Van city center and its near surroundings. According to the results, suggestions were developed for creating and strengthening connections between the green infrastructure components of the study area.

\section{Material and Method}

The study area is located in Van province in the Van Lake Closed Basin of the Upper Murat-Van Section of the Eastern Anatolian Region, between $42^{\circ} 40^{\prime}$ and $44^{\circ} 30^{\prime}$ east longitude and $37^{\circ} 43^{\prime}$ and $39^{\circ} 26^{\prime}$ north latitude. The study area covers Van Metropolitan Municipality borders with an area of 30,734 hectares. In order to determine the green infrastructure components of Van city center and its surroundings, the study was completed in six steps; I) Literature review and determination of the study's scope and the confines of the study area, II) Field survey and data collection, III) Determination of the necessary ecological and cultural parameters for the development of green infrastructure system in the area, IV) Analysis of ecological and cultural parameters, V) Study results and VI) Discussion and conclusion (Figure 2).

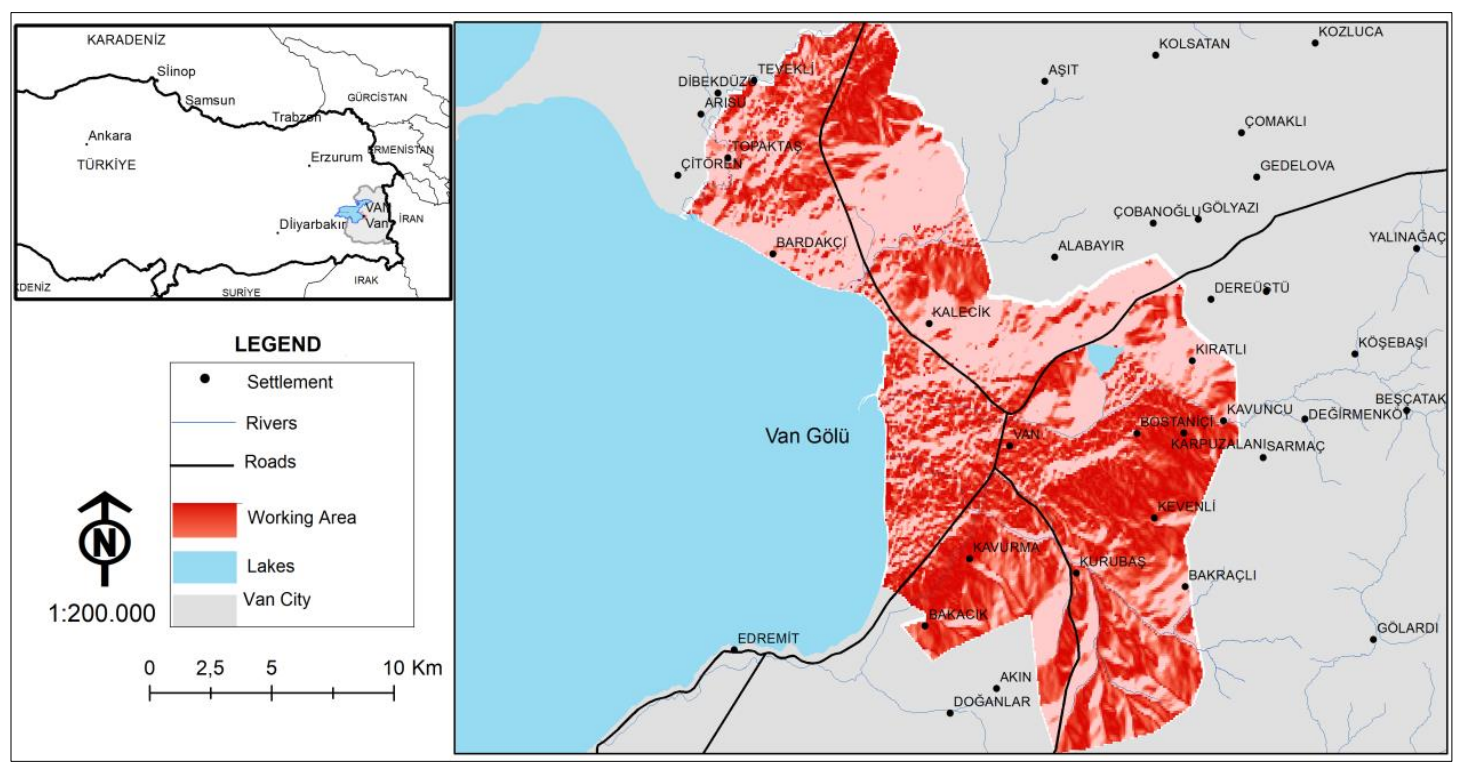

Figure1. Geographic location of the work area

In accordance with the approach and definitions in the related literature, it was decided that the green infrastructure components to be determined for this study should be landscape units with the properties of core areas, matrixs and corridors. While determining GI components, designation, classification and weighted comparison of environmental parameters were completed by referring to the studies done by Coşkun Hepcan (2008) and Hector (2003). In this context, areas rich in natural and cultural properties and biodiversity, as well as in important key points for green infrastructure, were termed core areas; landscape units whose biodiversity was not as varied as core areas, or whose land cover was not homogenous were termed as matrix (area); and natural rivers and corridor-shaped open-green areas were termed corridors. Based on Dramstad et al. (1996), natural streams are regarded as ecological corridors and ecological corridor analysis has not been conducted in the study. The natural stream corridors which are longer than $5 \mathrm{~km}$ and have continuity in the study area are identified as the corridor component of the GI system. This is due to the fact that streams of more than $5 \mathrm{~km}$ support the integrity of aquatic and other ecological processes provide opportunities for recreation along the coastline and support air circulation. At the same time, according to the shore law number 362, streams regarded as corridors together with their $200 \mathrm{~m}$ near surroundings.

\section{Literature review; determination of the study's scope and the confines of the study area}

In order to form a theoretical and methodological basis for this study, foreign and national literature covering the concepts and approaches of green infrastructure, and green infrastructure components - core areas, corridor, and area-was studied. 


\section{Field survey and data collection}

The study area was directly observed through seasonal field surveys between 2015-2017. During the field surveys, the conditions of the study area's existing green infrastructure components were surveyed taking into account the pressure of construction, transportation, urban sprawl and other human activities. The study area was the main material of the study. In addition, the digital vector data on the soil, plant cover, hydrology, important natural areas, protected areas and land use, population and transportation system features in the study area are also among the materials of the study and these data obtained from Van Metropolitan Municipality and the local branches of related ministries of the state. For the analyses in the study, a trial version of ArcGIS 10.2 was used.

\begin{tabular}{|c|c|c|}
\hline \multicolumn{3}{|c|}{$\begin{array}{l}\text { II. Land survey and data collection } \\
\text {-Field observations and photographing } \\
\text {-Soil, vegetation, hydrological structure, important natural areas and } \\
\text { habitats, slope status, height groups, land use - land cover, protected areas, } \\
\text { population, transportation data provision and preparation }\end{array}$} \\
\hline \multicolumn{3}{|c|}{$\begin{array}{l}\text { III. Determination of the necessary ecological and cultural parameters for } \\
\text { the development of green infrastructure system }\end{array}$} \\
\hline \multicolumn{3}{|c|}{$\begin{array}{l}\text { IV. Analysis of the necessary ecological and cultural parameters for green } \\
\text { infrastructure development }\end{array}$} \\
\hline \multicolumn{3}{|c|}{ V. Analysis of ecological and cultural parameters } \\
\hline $\begin{array}{l}\text { a. Conversion of ecological } \\
\text { and cultural parameters } \\
\text { into raster format }\end{array}$ & $\begin{array}{l}\text { b. Density analysis; } \\
\text { Population and road } \\
\text { data }\end{array}$ & \multirow{3}{*}{$\begin{array}{l}\text { Determination } \\
\text { of green } \\
\text { infrastructure } \\
\text { components } \\
\text { (core, area, } \\
\text { corridor) }\end{array}$} \\
\hline \multicolumn{2}{|c|}{$\begin{array}{l}\text { c. Reclassification of data in raster format according to } \\
\text { green infrastructure components }\end{array}$} & \\
\hline \multicolumn{2}{|c|}{$\begin{array}{l}\text { d. Weighting according to the compliance of the green } \\
\text { infrastructure with the parameters classified }\end{array}$} & \\
\hline \multicolumn{3}{|c|}{ VI. Research Findings } \\
\hline \multicolumn{3}{|c|}{ VII. Discussion And Conclusion } \\
\hline
\end{tabular}

\section{Determination of ecological and cultural parameters}

The twelve parameters determined through the literature review and the data obtained in the study context can be classified into two groups: ecological parameters and cultural parameters. Accordingly,

- Ecological parameters include plant cover, hydrological elements, soil composition, topographical form, altitude and slope, important nature areas, and habitats

- Cultural parameters include land use/land cover, protected areas, population density and road density.

\section{Analysis of Ecological and cultural parameters}

\section{a. Conversion of Ecological and cultural parameters to raster format}

For the analysis of the maps obtained as vector data from the related organizations, the data was converted to raster format using the Spatial Analyst Tools in ArcGIS 10.2. All of the data layers in the analyses were 
in 10 -meter samples $(100 \mathrm{~m} \times 100 \mathrm{~m})$. Thus, the analyses were completed using raster data sample layers on $1000 \mathrm{~m}^{2}$ grids as a basis.

\section{b. Density analyses}

While determining the transportation network, a road map was produced by using village roads, roads and railways. Village roads are mostly stabilized roads and, single-lane roads. Highways (main roads) are covered with asphalt and double lane roads. The road density data were generated using the Spatial Analyst module in the ARCGIS 10.2 environment. Areas where the road density is high are determined as areas not suitable for GIC. Population density map was produced with ARCGIS 10.2 Spatial Analyst module by using population data of settlements in the research area. Settlement areas with a high number of population are determined as not suitable for GIC.

\section{c. Re-classification of ecological and cultural parameters}

All of the ecological and cultural parameters of the study area were classified according to the GIC in order to evaluate them in the same category; areas with the highest appropriateness were scored as 1, appropriate (suitable) areas 2 and non-conforming (unsuitable) areas as 3 (Table 3). According to the above mentioned level of conformity and point values, all parameters were classified in this context and scored (Table 4).

\section{d. Weighted comparison of ecological and cultural parameters}

The reclassified parameters were compared with weighted points according to their importance in the development of the green infrastructure in the study area. Accordingly, the parameters were weighted to be equal to 1 of the total scores (Table 5). Then by overlaying of all parameters on a single map, the suitability of the study area for GIC was determined. In weighting, the scores of ecological parameters and protected areas are weighted higher than other parameters because they are richer in terms of biodiversity than other parameters and they support the ecological processes in the study area.

Table 3.Definition of suitability level and scoring values

\begin{tabular}{|l|l|c|}
\hline Suitability level & Definition & Score (Index /importance) \\
\hline Highly suitable areas & $\begin{array}{l}\text { Areas with a high potential for founding } \\
\text { and developing green infrastructure } \\
\text { systems (GIS) }\end{array}$ & $1-1,8$ \\
\hline Suitable areas & $\begin{array}{l}\text { Areas with potential for founding and } \\
\text { developing GIS }\end{array}$ & $1,8-2,5$ \\
\hline $\begin{array}{l}\text { Not very suitable } \\
\text { areas/unsuitable areas }\end{array}$ & $\begin{array}{l}\text { Areas without potential for founding or } \\
\text { developing GIS }\end{array}$ & 3 \\
\hline
\end{tabular}

Table 5. Ecological and cultural parameters and weighted scores

\begin{tabular}{|l|l|}
\hline Ecological and Cultural parameters & $\begin{array}{l}\text { Weighted score (Degree of } \\
\text { Importance) }\end{array}$ \\
\hline Soil composition & 0.1 \\
\hline Plant cover & 0.1 \\
\hline Important nature areas and habitats & 0.2 \\
\hline Hydrological elements & 0.2 \\
\hline Slope class & 0.05 \\
\hline Land use/land cover & 0.05 \\
\hline Protected areas & 0.2 \\
\hline Transportation network & 0.05 \\
\hline Population density & 0.05 \\
\hline
\end{tabular}


Table 4. Re-classified ecological and cultural parameters and scores

\begin{tabular}{|c|c|c|c|}
\hline $\begin{array}{l}\text { Ecological and Cultural } \\
\text { Parameters }\end{array}$ & \begin{tabular}{|l}
$\begin{array}{l}\text { Score } \\
\text { (Importance) }\end{array}$ \\
\end{tabular} & $\begin{array}{l}\text { Ecological and Cultural } \\
\text { Parameters }\end{array}$ & $\begin{array}{l}\text { Score } \\
\text { (Importance) }\end{array}$ \\
\hline Soil composition & & Land cover & \\
\hline Alluvial soil & 1 & Steppe & 3 \\
\hline Colluvium soil & 1 & Grassland & 2 \\
\hline Hydromorphic soil & 1 & Meadow & 1 \\
\hline Red-brown soil & 2 & Hydrological Elements & \\
\hline Brown soil & 2 & Rivers $>5 \mathrm{~km}$ & 1 \\
\hline Regosol soil & 2 & Rivers $<5 \mathrm{~km}$ & 2 \\
\hline Stony-rocky areas & 3 & Lakes & 1 \\
\hline $\begin{array}{l}\text { Topography } \\
\text { Slope Class }\end{array}$ & & $\begin{array}{l}\text { Important nature areas } \\
\text { and habitats }\end{array}$ & \\
\hline Flat $0-2 \%$ & 1 & $\begin{array}{l}\text { The borders of important } \\
\text { nature areas }\end{array}$ & 1 \\
\hline Slightly sloped 2-4\% & 1 & $\begin{array}{l}\text { Permanently } \\
\text { salt/soda/alkaline swamps }\end{array}$ & 1 \\
\hline Moderately sloped 4-6 \% & 2 & Iranian-Anatolian steppes & 3 \\
\hline Sloped 6-8 \% & 3 & Terrestrial swamps & 2 \\
\hline Land use /Terrain & & Protected areas & \\
\hline Meadow-grassland & 1 & $\begin{array}{l}1^{\text {st }} \text { Degree Archeological } \\
\text { Site Area (ASA) }\end{array}$ & 1 \\
\hline Orchards & 1 & $\begin{array}{l}1^{\text {st }} \text { Degree Archeological } \\
\text { Site Area }\end{array}$ & 1 \\
\hline Forested areas & 1 & $\begin{array}{l}2^{\text {nd }} \text { Degree Archeological Site } \\
\text { Area }\end{array}$ & 1 \\
\hline Lakes & 1 & $\begin{array}{l}3^{\text {rd }} \text { Degree Archeological Site } \\
\text { Area }\end{array}$ & 1 \\
\hline Reed-beds-swamp areas & 1 & Other areas & 3 \\
\hline Dry agricultural areas & 1 & Population Density & \\
\hline Rural settlements & 2 & Population: $<10,000$ & 1 \\
\hline Urban settlements & 3 & Population: $10,000-20,000$ & 2 \\
\hline Stony-rocky areas & 3 & Population $>20,000$ & 3 \\
\hline Storage areas & 3 & Road Density & \\
\hline Industrial areas & 3 & $0-15 \mathrm{~m}$ & 1 \\
\hline Airports & 3 & $15-30 \mathrm{~m}$ & 2 \\
\hline Stone-sandpit & 3 & $30-45 \mathrm{~m}$ & 3 \\
\hline Military areas & 3 & $45-60 \mathrm{~m}$ & 3 \\
\hline
\end{tabular}

\section{Results}

Pressures on and destruction of the landscape elements in the study area

According to the findings obtained from the land survey and observations,

- The surroundings of Van Fortress, the eastern shore of Lake Van and wetlands are under high pressure and damaged. Eutrophication, visual pollution and habitat fragmentation are seen on the shores of Lake Van as a result of construction refuse, rubbish and sewage dumped and, also due to the burning of reed-beds. These areas, in which poaching was also observed, have had their ecological functions and integrity damaged (Figure3). 
- The housing, transportation and open-green space policies and practices in the study area neglect the integrity of the area's mountain, wetland, steppe and shore ecosystems, their functions and their importance for the ecological sustainability of the city (Figure 4).
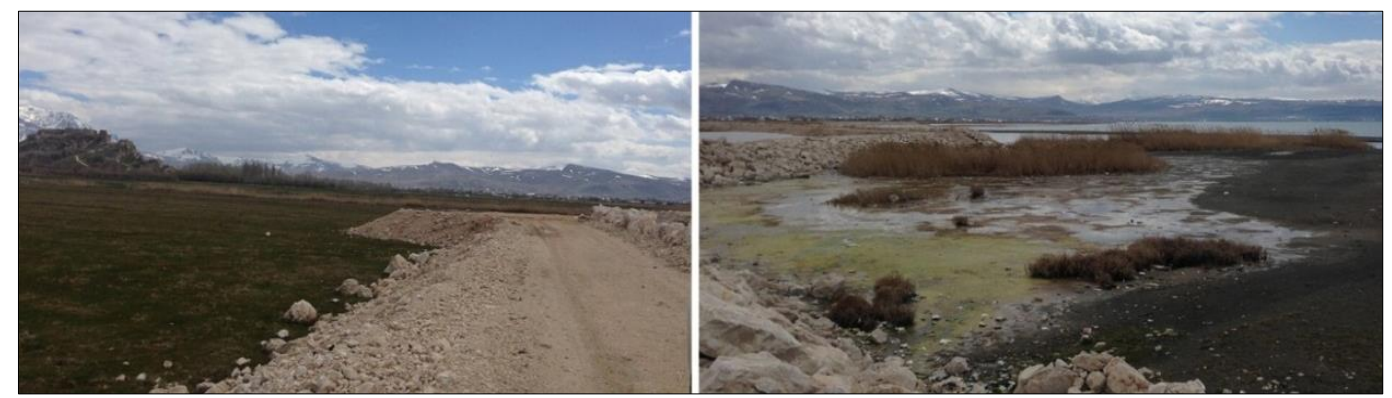

Figure 3. Wetland habitats on the shore of Lake Van and the vicinity of Van Castle

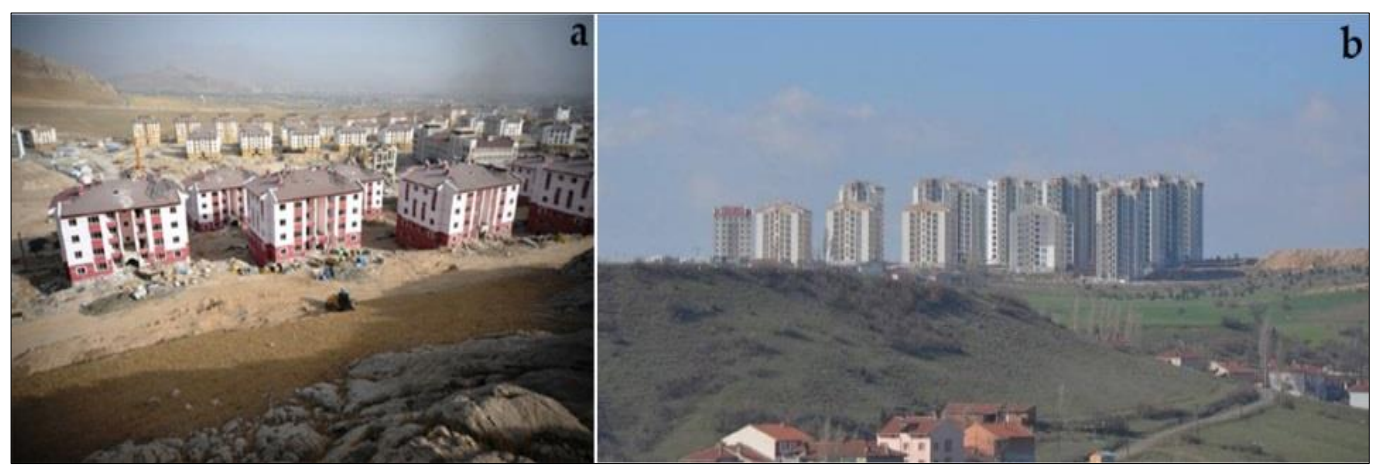

Figure 4.Mass housing settlements which fragment the landscape unity in (a) Van Plain Important Nature Area and (b) Mount Erek and Lake Turna Important Nature Area

\section{The suitability of green infrastructure components in the study area}

According to the weighted analyses results, the suitability index of the study area for green infrastructure development was between 1 and 3. The suitability ranges for GI components in the study area were determined as follows:

- Places with a value between 1 and 1.8: core areas; highly suitable for GIC development

- Places with a value between 1.8 and 2.5: matrixs; moderately suitable for GIC development

Places with a value between 2.5 and 3: not very suitable/unsuitable for GIC development

As a result of weighted score analyses, the most suitable areas in the study area for the development of green infrastructure components were the coast of Lake Van and its near surroundings, as well as places near to streams and Lake Sihke. City center and near surroundings, such as Kevenli, Karpuzalanı and Bostan settlements were the least suitable areas for the development of green infrastructure components, or unsuitable. The areas other than these were moderately suitable for the development of GIC (Figure 4). The natural stream beds and their banks in the study area were defined as corridors. Thus, the GIC in the study area were determined as 10 core areas (C), 16 matrix (A) and four corridors (K) (Figure 5).

\section{Core areas}

The largest of the core areas, core area 1 (C1) is located on the coast of Lake Van in the west of the study area. This core area of 1,627 ha is rich in natural and cultural landscape elements. The natural landscape elements in $\mathrm{C} 1$ are the shore of Lake Van and the wetland habitat on the lake shore; the cultural landscape elements are the Urartu-Tuşpa Necropolis $1^{\text {st }}$ Degree ASA, the Urartu-Tuşpa Necropolis $3^{\text {rd }}$ Degree ASA, the Van Castle $3^{\text {rd }}$ Degree ASA, and the Zeve Ruins $1^{\text {st }}$ Degree ASA. The C1 core area is located in the Van Plain Important Natural Area (INA) and has the properties of permanent soda/salt/alkaline swamp 
habitat, and its plant cover is predominantly meadow and reed-beds. The core area's habitats are home to the white-headed duck species Oxyura leucocephala, which, like a lot of water and shore plant and animal species, is endangered (Çiplak \& Gürkan, 2006). Its land use/land cover contains rural settlements, industrial and water-treatment plants, a university campus and dry agricultural areas.

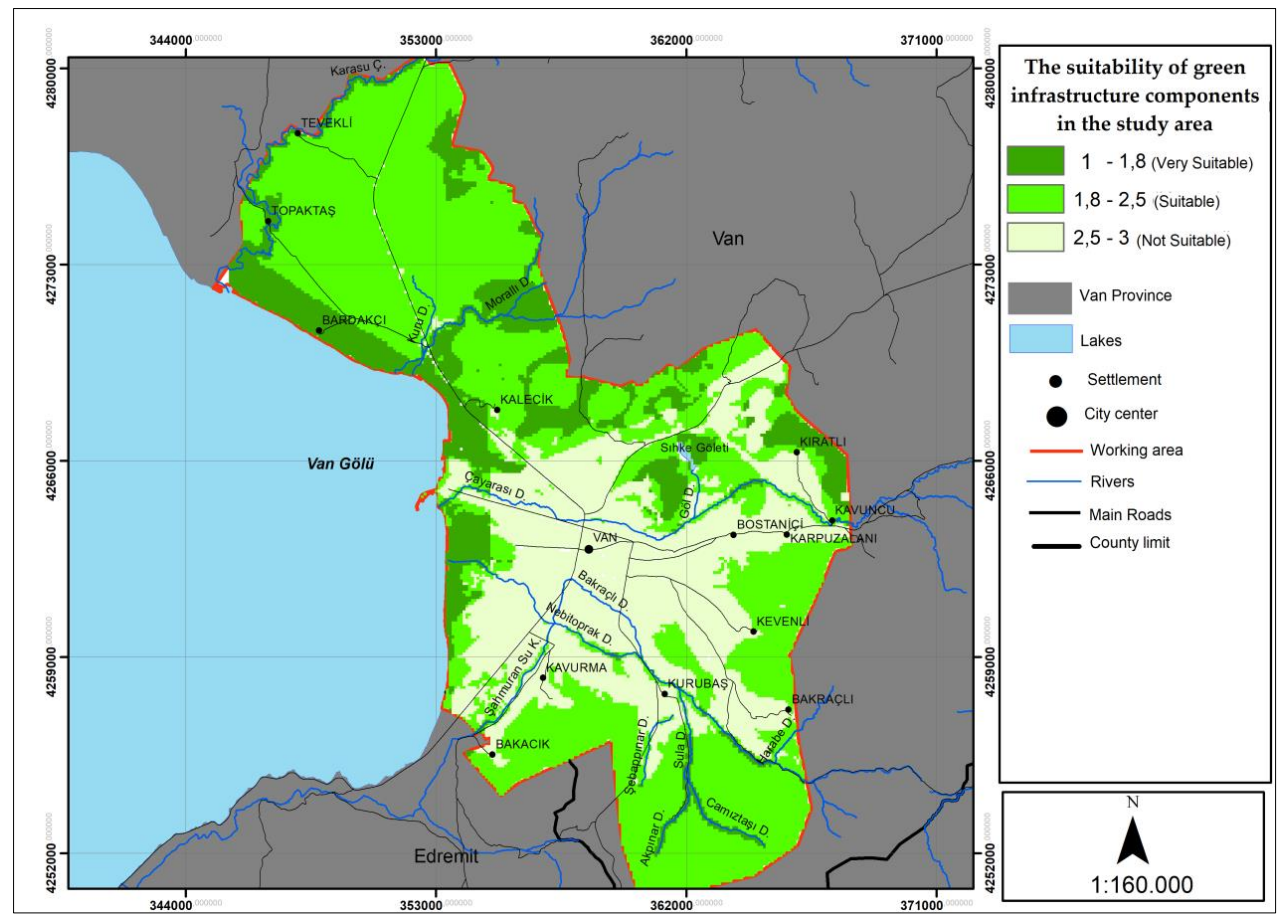

Figure 4.The suitability of green infrastructure components in the study are

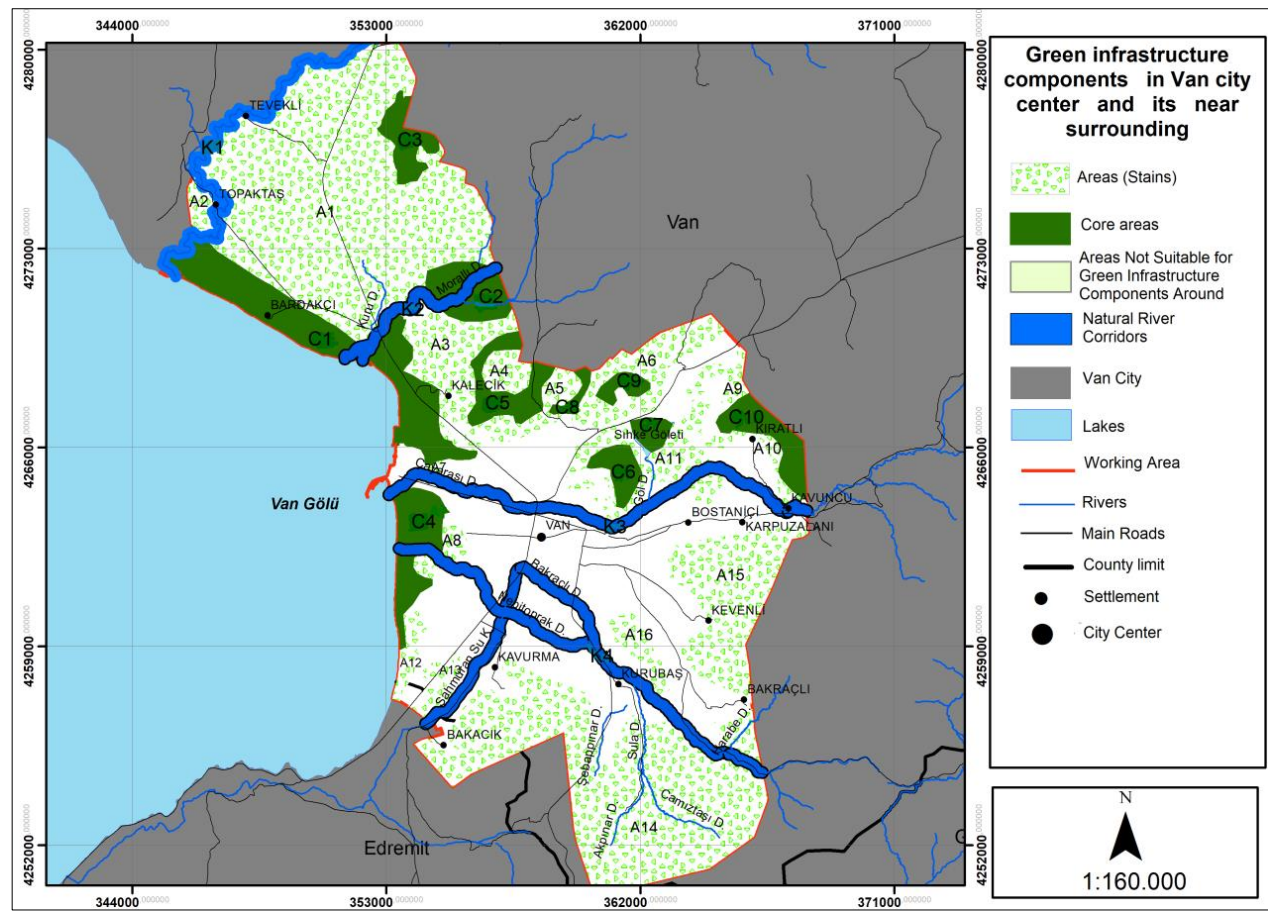

Figure 5.Green infrastructure components in Van city center and its near surroundings

Core area 2 (C2) is located on the eastern side of the study area. It is 508 ha in size, and the Morall and Osmangöl streams flow through it. As for its plant cover, $90 \%$ is meadow and the remaining part is steppe. 
This core area, which contains Iranian-Anatolian steppe and terrestrial swamp habitats, is located within the Van Plain Important Natural Area (INA), and the endangered butterfly species Archona pollinaris and Pseudophilotes bavius have been observed there (Çiplak\&Gürkan, 2006). The predominant land use in the core area is dry agriculture, and the soil type is in large part alluvial, with brown soil found in a few places. C3 is located in the northeast of the study area and is 427 ha in size. Located within the confines of the Van Plain INA, C3's plant cover is steppe and it has the habitat properties of the Iranian-Anatolian steppes with stony rocky areas and meadow-grasslands.

C4, which measures 539 ha, is located in the western part of the study area on the shore of Lake Van. Van Castle $1^{\text {st }}$ Degree Natural Site Area, Van Castle $1^{\text {st }}$ Degree ASA, Van Castle $2^{\text {nd }}$ Degree ASA and Van Castle $3^{\text {rd }}$ Degree ASA are located in C4. The core area's plant cover is meadow, and permanent soda/salt/alkaline swamp habitats are found there. These habitats host aquatic plant species such as Potemegetum pectinati, Scorzoneretum parviflora, Butometumum bellati, and Phragmites umaustrali, one fish species Alburnus tarichi (pearl mullet - endemic), two species of amphibian, two mammal species and 44 bird species, among which is the endangered Oxyura leucocephala (white-head) (Adizel et al., 2017). Approximately $90 \%$ of the area is made up of irrigated agricultural areas, and the remaining areas are settlements.

C5 is located in the northeast of the study area in the environs of the settlement of Kalecik, and it measures 427 ha. The habitat of the core area, in which steppe plant cover is predominant, has the properties of the Iranian-Anatolian steppes. The predominant land use in the core area, which contains the Kalecik Necropolis $1^{\text {st }}$ Degree ASA, is meadow-grassland. In addition, dry agricultural areas and stony-rocky areas are found in the area. C6 is located in the central part of the study area near the city center, and is 241 ha in size. The predominant land use in the core area is meadow-grassland and irrigated agriculture, and the Toprakkale Settlement $1^{\text {st }}$ Degree ASA is located there.

C7 consists of Sihke Pond and its surroundings, and is 129 ha in size. C7 is connected to the seasonal Göle stream and the Çayarası stream (Akköprü). It contains hydromorphic and alluvial soils, has a steppe plant cover, and habitats with Iranian-Anatolian steppe characteristics. The land use/terrain in C7 is irrigated agriculture. C8 and C9 are located in the northeast of the study area and have Iranian-Anatolian steppe habitat characteristics. The main land use/land cover in these core areas agriculture, grassland and meadowsas well as stony-rocky areas.

\section{Matrixs}

A1 covers a large area from the north of the study area toward its central parts, and is 6,065 ha in size. The largest area in the study area, A1 is bordered on the northwest by Karasu Creek (K1), on the southeast by the Morallı River (K2), and on the southwest by core area1. Topographically flat and nearly flat areas make up a large portion of this area and its slope varies between4-8\%. It contains regosol and brown soils as well as stony-rocky areas and is located within the borders of the Van Plain INA. The predominant plant cover in A1 is steppe, and it has the habitat characteristics of the Iranian-Anatolian steppes. A1 contains the Kuru River and the Katar River, and its area use/land cover consists of industrial areas, dry agriculture, warehouses and livestock farms. On the southwest side of this area is the Karasu Delta, and on its northwest side is $\mathrm{A} 2$, which is 18 ha in size and has similar properties.

A3 is in the central part of the study area bordered by C1, C5, C2 and K2, and is 929 ha in size. Between A3 andA1 is found the Osmangöl River, designated asK2. Consisting of mostly flat and nearly flat areas, the slope of $\mathrm{A} 3$ varies between 3-5\%. As the continuation of $\mathrm{A} 1$ and $\mathrm{A} 2, \mathrm{~A} 3$, which is located within the borders of the Van Plain INA, has steppe as its predominant plant cover and habitat characteristics of the Iranian-Anatolian steppes. The endangered butterfly species Archon apollinaris and Pseudophilotes bavius (Çiplak\&Gürkan, 2006,p. 386) were observed in the area. A3, which contains Kalecik and its nearby rural settlements, has mainly dry agriculture as its predominant land use, and stony-rocky areas are found in a few places.

Having similar properties, A4 (210 ha), A5 (372 ha) and A6 (116 ha) are contiguous areas found in the northeast of the study area. While the soil type in A4 andA6is brown, in A5 alluvial soil is found. The slopes of A4, A5 and A6 vary between 0-5\%, their predominant plant cover is steppe, and they have Iranian-Anatolian steppe habitat characteristics. The land uses/terrains in these areas are dry agriculture, stony-rocky areas, meadow-grassland and rural settlement areas. A7 is located near the shores of Lake 
Van between $\mathrm{C} 1$ and $\mathrm{C} 4$. The 51 ha area is connected to the Çayarası River, designated as K3. Although the predominant plant cover in A7 is meadow, reed-beds are also found there, and its habitat type is permanent soda/salt/alkaline swamp. As regards land use, dry agriculture and urban settlement areas are found there. Within A7'sborders is the Van Castle $3^{\text {rd }}$ Degree ASA. A8 is located in the west of the study area near C4, and its area is 620 ha. The Nebitoprak River passes through A8 and connects it to C4. While $85 \%$ of the area's slope varies between $0-2 \%$, in the rest of the area it is as high as $8 \%$. This areas soil types are alluvial, hydromorphic and colluvial, its plant cover is steppe and its habitat type is IranianAnatolian steppe. The primary land use/terrain in A8 is irrigated agriculture and urban settlement. A9 (177 ha) and A10 (258 ha) are located in the east of the study area. These areas have brown soil type, and their main plant cover is steppe. As regards their slope, they have a sloped structure that varies between 0-8\%. The land uses in A9 are meadow-grassland and dry agriculture, and in A10 they are irrigated agriculture, meadow-grassland, and urban settlement.

A11 is located in the inner part of the study area near C6, and is 99 ha in size. It is located near the city center, and Çayarası River passes through it. Most of its area has a slope varying between 4-6\%, but it also contains sections whose slope varies between 6-8\%. Its soil composition has areas of brown soil and stony-rocky areas. Steppe plant cover is predominant in the area, and its habitat characteristics are IranianAnatolian steppe. As regards land use, meadow-grassland and stony-rocky areas are found there. A part of the Urartu Toprakkale settlement $1^{\text {st }}$ Degree ASA lies within A11's borders.

A12 is located in the west of the study area on the shore of Lake Van and near C4 and A13. It is 171 ha in size. It has areas which are flat or nearly flat, and its slope varies between $0-2 \%$. The area's habitat characteristics are permanent soda/salt/alkaline swamp, and its plant cover is meadow. In A12, there are different land uses such as industrial, airport, urban settlements and wetlands. A13 is located in the southwest of the study area between A14 and A12, and is 217 ha in size. The area is connected to the Şahmuran River and the Nebitoprak River, designated as K4. Its topographic make-up is flat or nearly flat, and its slope varies between $0-2 \%$. It has permanent soda/salt/alkaline swamp habitat characteristics and meadow plant cover. Reeds are found in its meadow areas. It has different land uses such as irrigated agriculture, industrial areas, urban settlement areas, military areas and dry farming. Its soil consists of brown soil.

A14 is found in the south of the study area and is 4,629 ha in size. A large part of this area is slightly sloped at 3-4\%, and the Camıztaşı, Sula, Akapınar, Şebappınar, Bakraçlı and Harabe creeks run through it. Its soil composition is approximately $85 \%$ brown soil, and the rest is red-brown soil. A14 is located within the borders of the Mount Erek and Lake Turna Important Nature Area, and houses the endangered Astragalus ovatus (milkvetch), Bellevalia rixii (hyacinth), Marrubium vanense (Van hoarhound), Minuartia dianthifolia ssp. Kurdica (tıstıs - endemic), Ranunculus poluninii (buttercup), Stachys willemsei (pink calla lily - endemic), Taraxacum davisii (Erek dandelion - endemic), Thlaspi watsonii (pennycress), Verbascum linearilobum (mullein - endemic), Veronica vanensis (Van blue - endemic) plant species and Glaucopsyche arion and Tomares callimachus butterfly species (Adizel et al., 2006). About $85 \%$ of the area consists of meadow-grasslands, together with dry agricultural and stony-rocky areas. Yoncatepe Castle $1^{\text {st }}$ Degree ASA is located in A14.

A15 (1477 ha) and A16 (262 ha) are located in the east of the study area within the borders of the Mount Erek and Lake Turna Important Nature Area. Their plant cover and habitat are mountain steppe. A15 and A16 have brown soil composition and the slope of these areas varies between 0-8\%.The current land uses/land cover in A15 are irrigated agriculture, meadow-grassland and urban settlement, while in A16 the current land use is irrigated agriculture.

\section{Corridors}

K1 is Karasu Creek, running from the north of the study area toward the west. Its length within the study area is $21 \mathrm{~km}$. K1, which is located within the Van Plain INA and runs within its own banks, includes the Karasu Delta where it joins with Lake Van. Reed-beds line the shores of K1, and there are dry agricultural 
areas surrounding it. K1 provides a connection between A1, A2 and C1. K2 is the Morall Creek, which joins the northeastern part of the study area with its western part. It is $17 \mathrm{~km}$ in length, and near it are located the Kuru creek, the Osmangöl and the Katar creeks. K2, which is located in the Van Plain INA, runs in its natural bed and has not been canalized. This corridor provides a connection between A1, A3, $\mathrm{C} 1$ and $\mathrm{C} 2$.

K3, the Çayarası (Akköprü) Creek, runs uninterrupted straight from the eastern edge of the study area through to its western edge. Near K3 is the Göl Creek, which is a seasonal creek joining K3 to Sihke Pond. Starting in the Kavuncu area and passing through the city center, $17 \mathrm{~km}$-long $\mathrm{K} 3$ provides a connection between the city center and A7, A8, A10, A11 and C4. The section of this corridor that passes through the city center has been canalized, and its surroundings contain irrigated and dry agriculture, urban settlement and reed-beds and swamp areas.

K4 is the Nebitoprak Creek, $16 \mathrm{~km}$ in length and running from the southeast of the study area toward its western edge. It joins the city center to the nearby Şahmuran Canal. It runs through Kurubaş, Kavurma, Bakacık and the city center. K4 connects A8, A15, A16, A13, A14 and C4 with each other. This corridor, whose southwestern section is within the borders of the Mount Erek and Lake Turna Important Nature Area, is connected to the Bakraçlı, Harabe, Camıztaşı and Sula creeks. Different land use/land cover features are found in the area around K4: urban settlement, meadow-grassland, reed-beds and swamp, stony-rocky areas and industrial areas.

\section{Discussion and Conclusion}

In this study, green infrastructure components were determined in order to guide the development of a green infrastructure system which will improve the quality of urban life in Van city and its surroundings by forming connections between the natural and cultural landscape elements which are under the pressure of unsustainable land use. With this in mind, in the study, a green infrastructure system was taken as a planning strategy which contributes to the conservation of natural and cultural landscape components and at the same time to the improvement of quality of life in the city and its surroundings, and thus, to the sustainability of the city. The multi-functional quality of green infrastructure systems, which support the integrity of natural and cultural functions in urban areas and their surroundings, directed the choice of parameters used in the study and the assessment of their suitability for GI in terms of their functions In this context, the study consisted of two basic steps: (1) determination of the parameters for determining green infrastructure components, and (2) analysis and assessment of the parameters' suitability for GIC and the determination of core areas, areas and corridors. As a result of the study, suggestions were developed for the planning and application of green infrastructure systems in Van city and its near surroundings in the context of the condition and potentials of the designated GI components.

The method that was used in the study can be repeated in different areas and on different scales. One of the topics in this study that differentiates it from similar studies is the consideration of historical areas by treating them in the context of GIC parameters and additionally, with the status of protected areas highly suitable for GIC. In other studies with similar topics (e.g., Coşkun Hepcan, 2008; Hector, 2003 and Kopperoinen et al., 2014), historical areas were not given a place among the parameters for green infrastructure components. Another difference between this study and other similar studies is that in this study, the most suitable parameter from a GIC standpoint was given the lowest score, and the least suitable parameter was given the highest. Accordingly, after classification, the parameters, which were scored as 1,2 , or 3, increase in GIC suitability as they approach a value of 1 . Still another difference in the study's method as compared to that of other studies is that although in other studies, the areas defined as corridors were determined by re-classifying all the parameters and scoring them, in this study, natural rivers in the area were accepted as corridors without undergoing analysis to designate them as such. The reason for this is that the corridors determined in reference studies focused on an ecological network approach, which aimed towards easing the movements of mammal species and animal crossing. Thus, this study focused on the current condition of the bonds between the natural and man-made open-green space components in Van city center and its near surroundings, contributing to the city ecosystem by ensuring the sustainability 
of landscape functions through repairing and strengthening these bonds, and the improvement of urban recreation opportunities.

The results of the study showed that the existing green infrastructure components in Van city center and its near environment were mostly natural areas consisting of wetlands and steppe habitats in the surroundings of the city. As for the city center, as Coşkun Hepcan and Hepcan (2018) stated, similar to many other cities, it is extremely weak from green infrastructure component perspective. According to the results, approximately $15 \%$ of the study area was made up of core areas, $52 \%$ of matrixs, and the remaining part of river corridors and urban areas that are not very suitable or unsuitable from a GIC perspective. The fact that a large portion of the green infrastructure components in the study area were matrix and an extremely small portion consisted of corridors shows similarity to the size of the green infrastructure components determined by Coşkun Hepcan (2018) for Bornova (İzmir) and Tokuş (2012) for Sarıyer (İstanbul).

The wetlands on the shore of Lake Van, which are located in the west of the study area, were especially designated as core areas because of their high level of biodiversity in the form of plant and bird species, their regulatory ecosystem functions and the importance their landscape connectedness; other related studies also made similar designations (e.g., Weber et al., 2006; Ruiz et al., 2014). In core areas, in addition to reed-bed and swamp areas, creeks and historical areas are also found. As the rural qualities of the Van city's environment are, in large part, protected, and as a result of the high level of biodiversity in the rural areas, the core areas and matrixs in the study area were richer in native flora and fauna species than the corridors, whose natural structure has been severely damaged. In addition, a large portion of the core areas in the study area host cultural heritage elements from pre-historical and historical eras cheek-in-jowl with wetlands and steppe habitats. This situation requires that a future green infrastructure system should consider the GI components determined in the study area as a basis in an holistic conservation approach for natural and cultural landscape features; thus the system will strengthen not only the recreational functions, but as indicated by Orantes et al. (2017), social and cultural values and their benefits (e.g., landscape aesthetics, preservation of archaeological and cultural heritage, provision of accessible open spaces, opportunities for environmental education and strengthening the communities' sense of nature and quality of life, inspiration, sense of place, cultural diversity and social relations). In this context, C1, C4, C5 and C6 are critical GI components of the study area, in terms of both biodiversity and cultural richness.

In order to stop the current fragmentation of the wetland ecosystems in $\mathrm{C} 1, \mathrm{C} 2$ and $\mathrm{C} 4$ and to repair and protect these ecosystems, first of all, instead of treating them as valueless areas for dumping rubbish and construction refuse and discharging sewage, the local administration and local people should undergo awareness training to understand the huge ecological and social importance that they hold. Furthermore, in order to reverse the fragmentation and loss that has already occurred, wetland restoration and the planting of wetland plants on road side verges should be undertaken. Additionally, preventative measures against poaching in these wetland ecosystems should be increased and landscaping in harmony with the natural landscape features should be applied in these areas to encourage nature education and recreational use. Conservation of dry agricultural areas in the core areas will increase both their biodiversity and the social and economic benefits that they provide.

$\mathrm{A} 1$, as one of the areas characteristic landscape units with its natural traits, and due to its relatively undisturbed natural composition and location connecting $\mathrm{C} 1$ and $\mathrm{C} 3$, is in a position to perform important functions in the green infrastructure system in Van city center and its surroundings. Moreover, the construction of parks and gardens in the urban area will support the formation of bonds between the GI components in the study area. As A3, A4, A5, A6, A9, A10 and A11 are closely located and have similar natural characteristics, they can undertake the important function of providing connections between the green infrastructure components in the study area. The protection and fortification of dry agricultural areas and meadows-grasslands in A1, A3, A5, A6 and A7, which have undergone habitat fragmentation similar to A14, A13 and A12, will strengthen the functions of these units within the GI system. Movement of 
species should be eased by planting trees near the transportation lines and creating refuges in these areas to reduce the effects of habitat fragmentation and make ecological linkages.

The natural river/stream corridors in the study area such as K1, K2, K3 and K4 and their near surroundings have significant potential for waterside recreation activities. Running in its natural bed, K1 (Karasu Creek), in addition to its location within the Van Plain INA, is important for the Karasu Delta where it flows into Lake Van. It is an important area for biodiversity as a result of the reed-bed and swamp areas surrounding it and the wildlife harbored by these areas. Corridors are important ecological units from an urban ecosystem and urban quality-of-life standpoint because they allow air circulation and recreation potential in the study area. K3 (Akköprü Creek), which flows through the city center, is an important corridor because it allows wind flow in the city center and provides a connection between hydrological units in the city and its near surroundings. Construction and canalizing activities on K3 and the other corridors and their near surroundings will damage their functions. Accordingly, to stop the isolation that is occurring in these corridors, to reforge ecological connections and to improve the urban air quality, green bridges or ecological linkages should be used and the near surroundings of these areas should be supported with open-green space creation and management.

Accordingly, as Snäll et al. (2016) put forth, when green infrastructure components' ecological structure, location and the threats they face are taken into account, it becomes necessary to develop special planning strategies for their conservation and for strengthening the connections between them.

\section{References}

Adızel, Ö., Durmuş, A., Kaycı, L., Koyuncu, M., Özçelik, H., Özgökçe, F., Özkol, H. \& Ünal, M. (2006). Erçek Mountain and Turna Lake, In: Eken, G., Bozdoğan, M., İsfendiyaroğlu, S., Dicle T. K., Lise, Y.(eds.) Turkey's Important Natural Areas (in Turkish) (pp. 378-380). DoğaDerneği, Ankara.

Adızel, Ö.,Yıldız, M. Z., Ünal, M., Azizoğlu, E., Öztürk, F. \&Akman, B. (2017). Biodiversity of Van Reeds, Eastern Turkey (in Turkish). Commagene Journal of Biology, 1 (1): 31-41.

Ahern, J.(1995). Greenways as a planning strategy. Landscape and urban planning, 33(1-3), 131-155.

Ahern, J., 2007. Green Infrastructure For Cities:The Spatial Dimension. IWA Publishing, London.

Benedict, M. A. \& McMahon, E. T. (2012).Green infrastructure: linking landscapes and communities. Island Press.

Civic, K. \&Siuta, M. (2014).Green Infrastructure - Training Manual for Trainers. 5000 LG Tilburg Press, Yay. No: 90154, Hungary. 29.

Coşkun Hepcan, Ç. \& Hepcan, Ş. (2018). Urban green infrastructure analysis: The case of Bornova (in Turkish). Mediterranean Agricultural Sciences, 31, 37-43.

Çıplak, E. \& Gürkan, Z. (2006)Van Plain, In: Eken,G., Bozdoğan, M., İsfendiyaroğlu, S., Dicle T. K., Lise, Y.(eds.) Turkey's Important Natural Areas (in Turkish) (pp. 384-386). DoğaDerneği, Ankara.

Dramstad, W. E., James, D. O., and Forman, R.T.T. (1996). Landscape Ecology Principles in Landscape Architecture and Land-Use Planning. Harvard University Graduate School of Design, Island Press, and the American Society of Landscape Architects. 


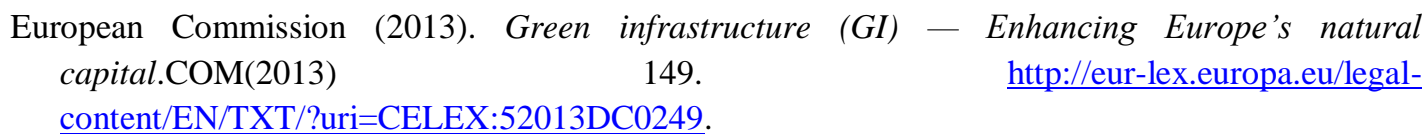

European Environment Agency (2017).What is green infrastructure? https://www.eea.europa.eu/themes/sustainability-transitions/urban-environment/urban-greeninfrastructure/what-is-green-infrastructure

Forman, R.T.T.(1995). Land Mosaics: The Ecology of Landscapes and Regions. Cambridge University Press, 652 p.

Goddard, M. A., Dougill, A. J. \& Benton, T. G. (2010). Scaling up from gardens: biodiversity conservation in urban environments. Trends in ecology \& evolution, 25 (2), 90-98.

Hepcan, Ç. C. (2008). Identification and planning of ecological networks as a sustainabile approach in nature conservation; the case of Çeşme-Urla peninsula (in Turkish), Ph.D. Thesis, Ege University. Graduate School of Natural and Applied Science Department of Landscape Architecture, 206 p., İzmir.

Hector, T. S. (2003). Regional landscape analysis and reserve design to conserve Florida's biodiversity, Ph.D. Thesis, University of Florida.

Jongman, R. H. \& Pungetti, G. (eds.). (2004). Ecological networks and greenways: concept, design, implementation. Cambridge University Press.

Kopperoinen, L., Itkonen, P. \& Niemelä, J. (2014).Using expert knowledge in combining green infrastructure and ecosystem services in land use planning: an insight into a new place-based methodology. Landscape Ecology, 29 (8), 1361-1375.

Lennon, M., Scott, M., Collier, M. \& Foley, K. (2017). The emergence of green infrastructure as promoting the centralisation of a landscape perspective in spatial planning - the case of Ireland. Landscape research, 42 (2), 146-163.

Lovell, S. \& Taylor, J.R. (2013). Supplying urban ecosystem services through multifunctional gren infrastructure in the United States. Landscape Ecology, 28 (8):1447-1463

Mell, I. C. (2009). Can green infrastructure promote urban sustainability? In: Proceedings of the Institution of Civil Engineers-Engineering Sustainability, Thomas Telford Ltd, 162(1), 23-34.

Orantes, M.J.C., Kim, J. \& Kim, J. (2017). Socio-Cultural Asset Integration for a Green Infrastructure Network Plan in Yesan County, Korea. Sustainability, 9 (2), 192.

Özeren, M. (2012). Scenerio building for Meles Delta and its environs in the context of 'green infrastructure'system (in Turkish), MSc Thesis, 145 p., Ege University. Graduate School of Natural and Applied Science Department of Landscape Architecture, İzmir.

Ruiz, L., Parikh, N., Heintzman, L. J., Collins, S. D., Starr, S. M., Wright, C. K., Henebry, G. M., van Gestel, N. \& McIntyre, N. E. (2014). Dynamic connectivity of temporary wetlands in the southern Great Plains. Landscape Ecology, 29, 507-516 
Snall, T., Lehtomaki, J., Arponen, A., Elith, J. \& Moilanen, A.(2016).Green infrastructure design based on spatial conservation prioritization and modeling of biodiversity features and ecosystem services. Environmental management, 57 (2), 251-256.

Tokuş, M. (2012).Urban green networks: case of Istanbul, Sartyer (in Turkish), M.Sc. Thesis, Istanbul Technical University, Graduate School of Science, Engineering and Technology, Landscape Architecture Program, İstanbul, s. 163.

TÜIK. (2018). Address Based Population Registration System Results. http://www.tuik.gov.tr/UstMenu.do?metod=temelist

Weber, T., Sloan, A. \& Wolf, J. (2006). Maryland's Green Infrastructure Assessment: Development of a comprehensive approach to land conservation. Landscape and urban planning, 77 (1-2), 94-110. 